\title{
FIGUR ISTRI YANG BIJAK DALAM MEMBINA RUMAH TANGGA KRISTEN BAHAGIA MENURUT AMSAL 31:10-30
}

\section{Fereddy Siagian}

Akademi Maritim Cirebon (AMC)

Email: fredy_siagian81@yahoo.com

\begin{abstract}
Abstrak
Pentingnya penelitian adalah untuk mencari dan menemukan data. Agar mengetahui mengenai figur seorang istri yang bijak dalam membina Keluarga Kristen Bahagia dan memberikan sumbangsih kepada keluarga Kristen mengenai pentingnya figur istri yang bijak dalam membina Keluarga Kristen Bahagia. Adapun ruang Lingkupnya ialah: Figur istri yang bijak ditinjau dari persepektif alkitabiah dan keluarga Kristen bahagia ditinjau dari perspektif teologis secara umum dan Alkitabiah. Metoda dan prosedur penelitian yang dilakukan oleh penulis adalah sbb: Melakukan penelitian perpustakaan (library research) melalui buku-buku perpustakaan pribadi yang topiknya berkaitan dengan masalah istri dan ibu yang bijak dan melakukan observasi lapangan dengan melalukan pengamatan terhadap istri-istri yang berhasil membina keluarganya. Karena pentingnya peranan istri dalam rumah tangga, maka penulis mengangkat masalah ini dengan judul, "Figur Istri yang Bijak Dalam Membina Rumah Tangga Kristen Bahagia Menurut Amsal 31:10-30”. Melalui peneelitian ini diharapkan para istri akan terus bertumbuh kearah kedewasaan. Mereka terus meningkatkan sumber daya manusia, dan bertumbuh dalam iman kepada Yesus Kristus yang adalah Kepala Gereja.
\end{abstract}

Kata kunci: Figur Istri Yang Bijak, Rumah Tangga Kristen Bahagia, Ams 31:10-30.

\section{Pendahuluan}

Dalam Kitab Kejadian 1, disaksikan bahwa setelah Allah membentuk langit dan bumi, maka kemudian pada hari yang keenam Allah menciptakan manusia yang diciptakanNya sama dan segambar dengan diri-Nya. Musa menyaksikan, "Berfirman Allah: Baiklah Kita menjadikan manusia menurut gambar dan rupa kita, supaya mereka berkuasa atas ikan-ikan di laut dan burung-burung di udara dan atas ternak dan atas seluruh bumi dan atas segala binatang melata yang merayap di bumi” (Kej. 1:26). Selanjutnya pada pasal 2, Ia membuat taman Eden, menempatkan manusia disana, dan membentuk rumah tangga yang pertama. Dalam hal ini musa menyaksikanya, "Tidak baik, kalau manusia itu seorang diri saja. Aku akan menjadikan penolong baginya, yang sepadan dengan dia" (Kej. 2:18). Kepada Adam, Allah memberi pasangan sekaligus 
penolong yang sepadan dengan dia, yakni Hawa istrinya. Setelah Allah membentuk rumah tangga dimaksud, maka ia memberkati mereka, dan kepada mereka diberikan mandat untuk beranak cucu untuk memenuhi bumi dan menjadi teman sekerja-Nya untuk berkuasa dan mengelola ciptaan-ciptaan yang ada.

Maksud dari Allah yang memberikan kepada Adam, istri yang menjadi penolong yang sepadan dengan dia, tentunya harus diartikan bahwa walaupun fungsinya berbeda dengan suami tetapi martabatnya kedudukannya di mata Tuhan, sama dengan suaminya. Istri hadir bukan sebagai pembantu suami, tetapi hadir menjadi penolong suami dalam membentuk sebuah rumah tangga yang dapat menyatakan dan menyaksikan kasih Tuhan sehingga nama-Nya dipermuliakan.

Istri yang diberikan Allah kepada Adam, sendi-sendi tulangnya lebih lemah dan agak berlainan bentuk serta susunan tubuhnya dari pada bentuk dan susunan tubuhnya sendiri. Ia memiliki perasaan yang lebih halus dan sikapnya lebih lemah lembut dari suaminya. Perbedaan-perbedaan ini memungkinkannya untuk menjadi penolong, penghibur bagi suaminya. Perbedaan-perbedaan itu memungkinkan mereka untuk saling mencintai, dan saling membutuhkan. "Menolong suami adalah salah satu kewajiban seorang istri. Menolong suami dalam mencapai suksesnya. Inilah yang telah dilakukan oleh Clementine Hozier kepada suaminya Winston Churchill. Winston Churchill bersaksi bahwa perjuangannya yang paling besar, paling berhasil ialah karena mengawini Clementine Hozier".

Ketika Allah membentuk rumah tangga di taman Eden, Alkitab menyaksikan bahwa ia menghendaki agar mereka berkembang biak serta memerintah seluruh bumi. Kitab Kejadian menyaksikan, “Allah memberkati mereka, lalu Allah berfirman kepada mereka: Beranakcuculah dan bertambah banyak; penuhilah bumi dan taklukkanlah itu, berkuasalah atas ikan-ikan di laut dan burung-burung di udara dan atas segala binatang yang merayap di bumi” (Kej. 1:28). Adalah maksud-Nya supaya mereka, melalui pernikahan dapat memiliki keturunan yakni keturunan yang mampu mengerti cinta kasih-Nya serta sanggup membalas cinta kasih tersebut.

Merawat dan mendidik anak adalah juga salah satu kewajiban yang penting bagi seorang istri. Dikatakan penting karena jika semua istri, menjadi seorang ibu benarbenar berhasil mendidik anak-anaknya di dalam Tuhan, maka akan muncul generasi generasi yang sungguh-sungguh mengasihi dan takut akan Tuhan. Akan hadir melalui 
rumah-tangga, anak-anak yang memiliki budi pekerti yang baik. Sungguh bahwa peranan istri dalam menciptakan dunia yang lebih baik, sangatlah besar. Dunia tidak akan berduka karena kemerosotan akhlak, jika para istri sebagai ibu dalam rumah tangga berhasil membentuk karakter yang luruh dalam diri anak-anak-Nya.

\section{Metode Penelitian}

Metodologi penelitian yang digunakan adalah metode kualitatif. Dimana metode kualitatif adalah yakin bahwa kebenaran ialah aktif dan bisa ditemukan cuma melewati pengamatan kepada orang-orang melewati hubungannya dengan situasi sosial mereka (Danim, 2002) Metode dan cara penelitian yang dilaksanakan oleh penulis adalah sebagai berikut: 1). Melakukan penelitian perpustakaan (library research) melalui buku-buku perpustakaan dan internet yang topiknya berkaitan dengan masalah pergaulan bebas (seks bebas) di kalangan Pemuda Kristen. 2). Melakukan observasi lapangan dengan melalukan pengamatan terhadap Pemuda yang sudah sempat terjerumus ke dalam pergaulan bebas.

\section{Hasil dan Pembahasan}

\section{Implementasi Figur Istri Yang Cakap Dalam Membina Keluarga Kristen Bahagia}

\section{Menurut Amsal 31:10-35}

Apa yang sebenarnya dicari dari para pria terhadap calon pendampingnya kelak? Apakah fisik atau kepribadian dari seorang wanita yang menjadi pertimbangan utamanya? Semua itu memang sulit ditebak, karena setiap pria memiliki karakter yang berbeda satu sama lain. Begitu pun dengan wanita. Lalu tipe wanita seperti apakah yang didambakan oleh seorang pria? Tentu saja ada kriteria-kriteria bagi seorang pria yang menjadi wanita idamannya sehingga ia mau memilih dan menjadikan wanita itu sebagai Istrinya. Namun yang dibahas dalam ini bagaimana figur seorang Istri yang bijak dalam membina keluarga Kristen yang bahagia. Jadi pembahasan ini akan difokuskan kepada peranan seorang Istri atau wanita dalam membangun keluarga Kristen yang bahagia.

Seorang Istri haruslah mengetahui Amsal 31:10-30: "Istri yang cakap, seorang yang dipercayai, rajin, berhikmat, menghormati suami, pengelola keuangan yang baik, memiliki kecantikan yang dari dalam, ramah.” 


\section{Istri yang Cakap}

Istri yang cakap adalah mahkota suaminya, tetapi yang membuat malu adalah seperti penyakit yang membusukkan tulang suaminya (Chasandra, 2016). Istri yang baik adalah kebanggaan dan kebahagiaan suaminya, Istri yang membuat suaminya malu adalah bagaikan penyakit tulang. Istri yang cakap adalah Istri yang bisa memenuhi panggilan kodrat kewanitaannya, yaitu dalam hal mengurus rumah, memasak, membimbing dan mendidik anak-anaknya serta membantu usaha suaminya, mengurus rumah tentu tidak harus istri yang mengerjakannya, namun istri yang cakap mampu untuk mengerjakan pekerjaan itu. Membimbing dan mendidik anak-anak merupakan peranan utama suami, namun istri dapat melakukannya.

Jika seseorang melakukan perbuatan baik, ia belum bisa dikatakan mempunyai ciri baik, akibat boleh jadi ia hanya berbuat baik jika sedang dalam perasaan senang atau sedang tidak ada masalah dan lainnya. Tetapi jika seseorang telah diuji dengan beragam ujian, dia ternyata selalu berbuat baik, sehingga ia bisa disebut memiliki ciri yang baik. Jadi ciri adalah mutu dari seseorang yang telah mengalami berbagai macam ujian. Jadi, arti dari istri yang cakap adalah istri yang telah mengalami berbagai macam ujian, dan ternyata selalu berbuat hal-hal yang luhur, mulia dan baik. Karena istri memiliki peranan sebagai penolong, hingga dalam tulisan ini, istri yang mempunyai ciri mulia, luhur dan baik, diibaratkan sebagai penolong ideal.

Penolong ideal ialah seorang istri yang suka atau semasa hidupnya, selalu melakukan hal-hal mulia, luhur dan baik. Sebelumnya, demi dibedakan antara penolong ideal dan penolong yang sebanding. Hawa adalah penolong yang sebanding bagi Adam, namun ini tidak mengartikan Hawa suka dan selama hidupnya melakukan hal-hal yang mulia bagi suaminya. Pada faktanya, Hawa terpengaruh dan jatuh kedalam dosa. Banyak suami yang melayani Tuhan, saat ini, memperoleh penolong yang sepadan baginya. Ini bukan berarti bahwa Istrinya selalu berbuat hal-hal yang luhur seumur hidupnya, atau bukan berarti Istrinya tidak memiliki kekurangan-kekurangan. Sepadan disini berarti cocok, sesuai/tepat, dalam arti, kekurangan-kekurangan dan kelebihan-kelebihannya sangat cocok untuk 
dipakai Tuhan bagi pembentukan karakter suami, agar sang suami ditolong dalam menyelesaikan tugasnya. Mendapat penolong yang sepadan, mungkin mudah.

\section{Istri yang bisa dipercayai}

"Hati suaminya percaya kepadanya, suaminya tidak akan kekurangan keuntungan. Ia berbuat baik kepada suaminya dan tidak berbuat jahat sepanjang umurnya" (Ams 31:11-12). Seorang istri yang dipercayai menyerahkan diri kepada suaminya. Semua yang dikatakan dan dilakukan olehnya ialah mendukung, membangun, mendorong, dan meneguhkan suamninya. Hidup sudah sukar bagi seorang pria dalam perjuangan di dunia ini tanpa ditambah lagi oleh seorang istri yang tidak mengerti atau tidak mendukung suaminya.

Pria akan merasa beruntung kala memiliki teman wanita yang dapat dia percaya untuk menjaga rahasianya. Anda mungkin tergolong wanita yang talk active, tapi sebaiknya berikan kepercayaan pada pasanganmu dengan menjaga rahasia yang telah dia sampaikan. Biasanya, wanita yang sering berkumpul bersama kawan-kawannya sering keceplosan menceritakan permasalahan yang sedang dihadapi pasangan. Hal ini membuat pria malas berbagi cerita. Pria akan sangat menghargai istri yang tidak hanya menjadi pendengar sejati, tapi juga dapat menjaga sesuatu hal yang berarti.

\section{Istri Yang Rajin}

Amsal berkata: Tangan orang yang rajin diberkati oleh Tuhan. Orang rajin pada umumnya disenangi oleh banyak orang. Dan orang yang rajin dimana pun ia tidak akan kekurangan (Sualang, n.d.). Seorang Istri yang rajin disenangi oleh suaminya. Pada umumnya seorang pria akan lebih senang melihat istrinya yang rajin. Baik rajin bekerja di dalam pekerjaan rumah tangga maupun rajin dalam menggapai karier, terlebih lagi rajin dalam beribadah kepada Tuhan.

Pasangan menikah yang sering datang menghadiri kebaktian gereja lebih bahagia dan nampak lebih berhasil dalam perkawinan mereka daripada yang jarang mengikuti kebaktian di gereja atau bahkan yang tidak pernah sama sekali, menurut suatu studi baru-baru ini.

"Peneliti menyatakan bahwa bukan hanya para suami yang rajin datang kebaktian yang menikmati perkawinan yang bahagia tetapi juga istri mereka lebih 
lagi mengalami kebahagiaan dalam perkawinan, dibandingkan dengan pasangan menikah yang para suaminya jarang menghadiri kebaktian secara rutin,"

Sesuai dengan pernyataan di atas dapat diketahui bahwa orang yang rajin, khusunya dalam beribadah akan mendapatkan kebahagiaan dalam keluarga. Apalagi kedua belah pihak antara suami dengan istri sama-sama rajin beribadah pada Tuhan. Demikianlah halnya dengan apa yang sudah diriset oleh para ahli dibawah ini.

Berdasarkan studi riset/penelitian, 70 persen dari suami yang menghadiri kebaktian di gereja secara teratur mengatakan mereka "sangat bahagia" dalam kehidupan perkawinannya, dibandingkan dengan hanya 59 persen dari suami yang tidak menghadiri ibadat keagamaan. Bagi wanita, hal serupa juga berlaku, yang mana bahwa kebanyakan dari mereka yang menghadiri kebaktian di gereja menurut laporan lebih bahagia dibandingkan dengan yang tidak.

\section{Istri Yang Berhikmat}

Hikmat merupakan pemberian Tuhan. Itu sebabnya ketika Salomo baru dilantik menjadi raja, ia tidak meminta harta kekayaan, tetapi yang diminta adalah hikmat. Apa sebenarnya hikmat itu? Hikmat adalah kebijaksanaan, boleh jadi di dalam bertindak dan mengambil keputusan, yang seadil-adilnya, sabar, tidak memihak, tidak merugikan orang lain, namun dapat diterima semua orang dan tidak melanggar firman Tuhan. Istri yang baik adalah istri yang memiliki hikmat. Pertanyaannya adalah Hikmat yang bagaimana harus dimiliki oleh seorang istri?

a. Istri Yang Berhikmat Mengasihi keluarganya (10-12)

Permata itu barang berharga, jarang sekali orang memilikinya di dalam jumlahnya yang banyak. Ia menjadi berharga justru karena jumlahnya sedikit dan langka. Kata Ibrani yang dipakai disini menunjukkan kesempurnaan yang agung, yang terbaik dan juga berkemampuan. Artinya sang Istri ini sangat gigih dan kreatif, nah istri semacam ini jarang ditemukan, harganya melebihi permata. (coba bandingkan dengan Amsal 8:11).

Di jaman modern semacam ini jarang menemukan istri yang model begini, di Indonesia banyak sekali temukan ibu-ibu muda yang sehabis melahirkan masih berpikir dia adalah anak gadis. Keluyuran kemana saja, sementara anaknya ditinggalkan kepada baby sitter. Bahkan ada bayi yang 
menangis kalau ibunya yang menggendong, karena hubungannya lebih dekat pada baby sitter atau inang pengasuhnya.

b. Istri yang berhikmat Memperhatikan kebutuhan keluarganya (13-dst)

Tidak seperti kebanyakan wanita jaman sekarang, yang selalu mengisi waktu kosongnya dengan pergi ke salon atau berkeliling ke shopping center, tetapi wanita berhikmat ini selalu mengisinya dengan hal-hal yang bermanfaat. Ayat 13 "Ia mencari bulu domba dan rami, dan senang bekerja dengan tangannya" artinya ia mempergunakan waktunya yang ada untuk membeli bahan-bahan mentah, memintal, menjahit dan menyulam. Ada tugas rumah yang harus dikerjakan oleh wanita ini, tidak hanya santai makan dan tidur serta jalan-jalan dan berfoya-foya.

\section{Istri Yang Menghormati suami}

Seorang suami pasti mersakan kedamaian dan percaya diri apabila perkataannya dan jati dirinya disukai dan dibanggakan oleh anggota keluarganya. Tetapi jikalau ia mengalami perlakukan tidak hormat, hingga terjadi pembrontakan dari anggota keluarganya, maka ia akan goyah dan krisis keluarga pun terjadi. Suami paling sering sakit hati bila istrinya sering mengkritiknya, terlebih bila kritik itu menjatuhkan harga diri suami di depan orang banyak. Suami akan merasa kesejukan bila sang istri selalu mendukung dan menopang segala rencananya. Harga dirinya sangat terangkat dan hal ini tidak dapat dibandingkan dengan materi.

Hormat mempunyai pengertian yang sama dengan taat dan tunduk walaupun dan apapun resikonya. Namun hormat atau tunduk terhadap suami hanya mau melakukan apabila hal itu tidak betentangan dengan firman Tuhan. Tetapi walaupun hal itu salah bukan berarti seorang istri menolaknya dan memberontak terhadap suaminya.

Tunduk kepada suami adalah menempatkan suami sebagai kepala keluarga yang dicintainya dan dijungjung tinggi. Tentulah amat mudah jikalau melakukannya untuk suami yang memiliki teladan hidup dan patut dicintai. Namun betapa sulitnya melakukan kepada suami yang tidak mampu menjadi suami yang baik. Alkitab mengajarkan tunduk bukan hanya karena suami baik, tetapi tunduk adalah juga kepada suami yang jahat itu kepada posisi semestinya. Jikalau ada keputusan penting yang harus diambil, keputusan sang suami yang tidak bijaksana 
itu tetap harus dihormati. Kalau keputusan itu kelihatannya salah, maka sang istri patut mendoakan dan berpuasa agar keputusan itu dapat berubah. Dengan doa, berpuasa, dan air mata keputusan yang salah dapat dirubahkan. Jikalau tidak berarti Tuhan sedang melatih dan menguji kesabaran sebagai seorang istri.

Adapun sebagai contoh seorang istri yang menghormati suami adalah sebagai berikut: Apabila suami melarang istri dan anak-anaknya ke gereja. Sebagai istri tentu menghormati keputusan itu, namun terus menggumulkan bagaimana agar hal itu dapat diubahkan. Untuk sementara istri bisa beribadah melalui persekutuan wanita yang umumnya berlangsung pada saat suami sedang bekerja. Sewaktu suami pulang, istri sudah kembali ke rumah.

\section{Istri Pengelola keuangan yang baik}

Amsal 31:11 mencatat bahwa, wanita yang berharga seperti permata itu mendapat kepercayaan penuh dari sang suami, serta dilanjutkan juga sebagai pengelola keuangan yang baik, sehingga tidak pernah membuat sanga suami rugi. Dengan demikian kehidupan wanita yang berhikmat ini turut mendukung, membangun, mendorong dan meneguhkan suaminya. Ia tidak pernah menyusahkan suaminya. Hidup di dunia ini sudah sukar bagi seorang pria dalam perjuangan di dunia ini, jangan ditambah lagi dengan seorang istri yang tidak mengerti atau tidak mendukung suaminya. Itu sebabnya Salomo di dalam tulisan Amsalnya berkata $(25: 24)$ Lebih baik tinggal pada sudut sotoh rumah dari pada diam serumah dengan perempuan yang suka bertengkar.

Pengertian keuangan disini adalah menejemen keuangan keluarga yaitu usaha untuk mengatur keuangan keluarga menjadi sehat dan seimbang. Sehat dalam pengertian setiap pengeluaran dan pemasukan dapat terdeteksi dengan jelas. Sehingga setiap rupiah yang dikeluarkan dapat dipertanggung jawabkan. Seimbang yaitu neraca pemasukan dan pengeluaran dapat dibukukan secara seimbang dengan meiliki saldo yang memadai.

Wanita adalah penolong bagi pria. Tuhan menempatkan wanita disisi pria bukan menjadi pengawas ataupun musuh bagi pria. Wanita juga di tempatkan Tuhan untuk pria bukan sebagai orang suruhan atau pun 'boneka' yang dapat diperlakukan sesukanya. Lebih mulia dari itu, semua wanita di tempatkan Tuhan sebagai penolong pria. Wanita yang cakap adalah wanita yang bijak. Salah satu 
sikap bijak wanita adalah dapat mengatur Apa pengertian wanita bijak dalam keuangan?

Mengerti Prinsip keuangan anak Tuhan. Apa prinsip keuangan anak Tuhan, yaitu:

a. (Mat $22: 21$ ). Mengembalikan apa yang menjadi bagian Tuhan

b. (Yes 55 : 2). Menggunakan sesuai dengan kebutuhan

c. (Amsal $12: 24)$. Rajin dan mengatur keuangan dengan baik

Bagaimana mengatur keuangan dalam terang Tuhan?

a. Belajar bersyukur dan mencukupi diri.

Cukupkanlah apa yang ada pada dirimu, dan jangan menginginkan yang lebih dari pada itu. Seorang istri harus mau beryukur atas pendapatan suaminya setiap bulannya. Jangan mau selalu ingin yang lebih walaupun itu penting. Karena apabila tidak ada ucapan syukur atas apa yang didapatkan oleh suami akan cenderung untuk melakukan tindakan yang tidak baik.

Seorang istri juga harus bisa mengatur keuangan dengan baik. Jangan belum sampai waktunya untuk gajian, uangnya sudah habis. Seharusnya walaupun gaji pas-pasan sebagai seorang istri harus berusaha untuk membuat saldo setiap bulannya, karena sedikit demi sedikit pasti akan menjadi bnayak. Bagaimana kalau orang yang tidak membuat saldo, apabila terjadi kejadian, kemalangan, maka akan sangat sulit untuk mencari-cari.

b. Jangan mengharapkan dan memaksakan diri untuk hal-hal yang bukan "milik" kita.

Sering sekali istri-Istri pengen memiliki apa yang dimiliki oleh tetangganya. Dengan demikian timbullah kerinduan untuk mengkredit dan ironisnya sampai timbul pencurian. Janganlah sampai istri mamaksakan kepada suaminya untuk memiliki kulkas apabila belum ada uang suaminya atau memiliki rumah mewah. Karena bisa saja akan membuat suaminya melakukan hal-hal yang kotor seperti korupsi yang penting kebutuhan istrinya terpenuhi.

c. Jangan pelit.

Orang pelit tidak akan masuk Sorga. Banyak ditemukan istri pada jaman sekarang ini hanya mau menerima uang dari suaminya. Tetapi saat suaminya membutuhkan sangat sulit dikeluarkan. Uang dari kantong suaminya bisa 
dikuras sampai habis, namun tatkala suami menginginkan buat beli bensin selalu ada alas an dan perkataan, kok boros sekali. Hal inilah yang membuat suami menjadi kurang terbuka dan jujur kepada istri masalah keuangan. Oleh sebab itu istri yang pelit terhadap suami. Maksudnya bukan juga boros, tetapi kalau memmang itu suatu kebutuhan yang urgen sekali harusnya dikasih.

d. Selalu bawa dalam doa.

Penghasilan sedikit sekali pun selalu harus di doakan supaya Tuhan mencukupinya seperti Tuhan memberkati 5 Roti dan 2 Ikan. Doakan hasil gaji itu doakan pekerjaan itu supaya terus menerus boleh mendapatkan hasil dari tempat itu.

e. Hati-hati dengan sesuatu yang discount atau murah.

Pada umumnya memang istri senang yang namanya belanja. Apalagi ada discount dan harga murah. Dengan adanya discount seperti ini membuat istri sering tergiur dan belanja banyak-banyak sehingga lupa hal-hal yang paling penting dan anehnya yang harusnya uang itu jatah buat satu bulan sudah habis dua minggu.

\section{Istri Yang Memiliki Kecantikan yang dari dalam (Inner beauty)}

Inner Beauty adalah kecantikan batiniah yang dapat kelihatan dari sikap dan perbuatan seseorang dalam kehidupan sehari-hari. Hal ini menjadi bahan perhatian bagi kaum pria saat ini. Memang saat pertama sekali seorang pria melihat wanita itu ialah kecantikan fisik, namun setelah berjalannya waktu kecantikan itu akan bisa pudar kembali apabila kecantikan dari dalam atau inner beauty ini tidak ada.

Wanita bijaksana ini bukan hanya tahu merias diri, tetapi baginya yang paling penting adalah kecantikan di dalam hatinya yang terdalam. Apalah artinya dia berwajah cantik, namun hatinya tidak takut pada Tuhan. Ayat 30 mencatat "Kemolekan adalah bohong dan kecantikan adalah sia-sia, tetapi Istri yang takut akan TUHAN dipuji-puji”. Semua orang merindukan puji-pujian semacam itu?

Bukan hanya urusan fisik semata yang menjadi pertimbangan utama para pria. Namun lebih daripada itu adalah kecantikan dari dalam diri wanita itu sendiri alias inner beauty yang merupakan target utama para pria dalam mencari pujaan hatinya. Tidak dipungkiri tubuh yang proposional dan wajah cantik yang dimiliki oleh seorang wanita, sering membuat mata pria terpanah, tapi setelah si pria ingin 
mengenal wanita tersebut lebih jauh lagi, yang didapatnya hanyalah tampilan luarnya saja yang ok, sedangkan kepribadiannya tidak balance. Jadi keseimbangan antara kecantikan luar dan dalam adalah faktor penentu seorang pria menjatuhkan pilihannya terhadap wanita idamannya.

Cantik menurut ukuran siapakah yang akan kita bangun? Cantik selera lakilaki, Cantik selera Wanita, atau cantik selera Tuhan. Ternyata Tuhan juga berselera dengan kecantikan, sebab Ia menciptakan manusia itu baik adanya. Berdampingan dengan "orang yang cantik jasmani" akan membanggakan, tetapi yang disertai dengan "cantik rohani" akan lebih menyukakan. Namun, banyak kaum hawa yang lebih suka diam dalam jebakan cantik standar pria

Demikianlah halnya seorang istri Salomo, yang disebutkan dengan gadis Sulam, sebenarnya dia adalah wanita yang jelek, hitam dan tidak menarik secara fisik. Namun dalam Alkitab dikatakan dari seribu orang istri Salomo, dialah yang paling disayangi oleh Salomo.

\section{Kesimpulan}

Isteri adalah seorang perempuan yang telah memiliki suami yang disahkan menurut undang-undang yang berlaku di sebuah Negara dan atau diteguhkan dihadapan Tuhan dan jemaat. Keberadaannya adalah untuk menjadi penolong bagi suami dalam membentuk suatu keluarga yang berbahagia yang berpusatkan Kristus, dan mampu juga memperkenalkan Dia di tengah-tengah kehidupan rumah tangganya. Seorang isteri Kristiani yang menjadikan Tuhan Yesus sebagai pemilik atas hidupnya, pusat sembahan dan kekuatannya, harus memiliki kualifikasi-kualifikasi yang akan penulis sebutkan dibawah ini, yakni:

\section{Istri yang sudah dilahirkan kembali}

Kelahiran kembali atau lahir baru adalah sebagai suatu tindakan oleh Roh Kudus, yang membawa perubahan dalam seluruh pandangan pribadi seseorang. Suatu perubahan yang dikerjakan oleh Roh Kudus yang membuat seseorang menjadi baru.

\section{Istri yang hidup dalam kekudusan.}

Kekudusan atau pengudusan memiliki pengertian bahwa Allah adalah kasih adanya, melakukan suatu tindakan untuk memisahkan, mengkhususkan, menyucikan seseorang pada saat ia menyatakan imannya pada Yesus Kristus 


\section{Istri yang memiliki moral yang baik.}

Ribka merupakan teladan bagi para calon istri. Disamping sebagai seorang gadis yang cantik, ia sanggup menjaga kesuciannaya, keperawanannya sebelum menikah. Seorang calon istri Kristen yang baik, harus hidup dalam kesucian supaya menjadi berkat bagi keluarganya.

\section{Istri yang memiliki kecantikan batiniah.}

Kecantikan bukanlah semata-mata ditentukan oleh sifat-sifat fisik sementara, tetapi watak, sikap dan tingkah laku serta nilai-nilainya yang terbentuk melalui pengetahuan yang dipelajari dan pengalaman yang dialami bersama Tuhan.

Seorang Isteri haruslah mengetahui Amsal 31: 10-30: "Isteri yang cakap, seorang yang dipercayai, rajin, berhikmat, menghormati suami, pengelola keuangan yang baik, memiliki kecantikan yang dari dalam: Cakap, Seorang yang dipercayai, Rajin, Berhikmat, Menghormati suami, Pengelola keuangan yang baik, Kecantikan yang dari dalam (Inner beauty) 
Fereddy Siagian

\section{BIBLIOGRAFI}

Chasandra, L. M. (2016). Jenis Makna Dalam the Book of Proverbs. Jurnal Elektronik Fakultas Sastra Universitas Sam Ratulangi, 3(1).

Danim, S. (2002). Menjadi peneliti kualitatif. Bandung: pustaka setia.

Sualang, F. Y. (n.d.). Analisa Sifat Kejujuran sebagai suatu Pembentukan Karakter menurut Amsal 10: 2-3.

Yayasan Komunikasi, Bina Kasih.OMF, "Tafsiran Alkitab Masa kini 2", Jakarta, Cempaka Putih, 1991

Wietsbe, Warren.W, “Kaya Di Dalam Kristus”, Bandung,, Yaysan Kalam Hidup, 2001

Wirradinata, Eddy, "Istri Gembala Sidang", Bandung, Lembaga Literatur Babtisan, 2001

Wriht, Norman.H, "Komunikasi Kunci Pernikahan Bahagia", Yogyakarta, Gloria Graffa, 2003 